\title{
The Effect of Network-Based Learning Discipline as Learning Outcomes Indicators for Mathematics Students in UNMUH Ponorogo
}

\author{
Azzahrotul Jannah ${ }^{1, *}$ Imam Sujadi $^{2}$ Siswanto $^{3}$ \\ ${ }^{I}$ Postgraduate of Mathematics Education Study Program, Faculty of Teacher Training and Education, \\ Universitas Sebelas Maret, Indonesia \\ ${ }^{2}$ Faculty of Teacher Training and Education, Universitas Sebelas Maret, Indonesia \\ ${ }^{3}$ Faculty of Mathematics and Natural Sciences Universitas Sebelas Maret, Indonesia \\ * Corresponding author. Email: azzahrotuljannah@student.uns.ac
}

\begin{abstract}
Problems in measuring online-based learning. in higher education, for example, the limitations of material explanations and internet signal barriers, so that the material presented by lecturers is not clear, making students have serious learning discipline. Therefore, learning discipline is very important in achieving learning outcomes during online-based learning. The motivation behind this research is to determine students' expectations in taking the results of learning disciplines during online learning and the relationship between learning disciplines and learning outcomes during online-based learning. This exploration is a summary study that uses a quantitative methodology. The subjects studied consisted of 67 dynamic students of UNMUH Ponorogo mathematics education in the even semester of the 2020/2021 academic year. The information diversity instrument is a survey of learning disciplines and a data collection of learning outcomes cards. Examination of information using descriptive statistical analysis and basic linear regression analysis. The results showed that online learning discipline can be used as an indicator of student learning outcomes at UNMUH Ponorogo and the higher student learning discipline, the higher student learning outcomes. This shows that online learning discipline has a significant contribution to the consequences of student learning measures, so students can improve learning discipline so that student learning outcomes can increase.
\end{abstract}

Keywords: Learning discipline, Online, Student learning outcomes, Arithmetic education.

\section{INTRODUCTION}

Towards the end of 2019, the world was shocked by the outbreak of the Corona virus infection which initially appeared in Wuhan, China [1]. Corona virus is another type of infection with indications of hacking, severe respiratory disorders such as shortness of breath and fever [2]. The Corona virus disease 2019 or Covid-19 [3] or SARS-Cov-2 [4] pandemic outbreak has disrupted and changed how we socialize, work, and learn. Since the pandemic began, much human activity has transitioned online. The profound effects of the pandemic are being especially felt in education. For education, the pandemic is both a challenge [5] and an opportunity [6]

Corona virus has spread all over the world, remember for Indonesia. The corona virus began to spread and attack Indonesian citizens on March 2, 2020 [7]. The spread of the corona virus was so fast that the Indonesian government set a lockdown status in several areas to break the chain of the spread of the Corona virus [8]. This has killed many charitable activities in the country, one of which is educational activities.

The teaching and learning process which is generally done up close and personal at this time due to the Corona virus has switched to network-based 
learning, both at the school and university level to prevent the spread of the Corona virus. This was done based on the results of a decree from the Ministry of Education and Culture No. 36962/MPK.A/HK2020 related to online-based learning for the prevention and handling of the Corona virus [9]. Online-based learning is an act of learning between teachers and students without real contact using the internet network [10]. Internet learning techniques are divided into 2 types, namely specifically coordinated and uncoordinated. Coordinated learning is communication between teachers and students directly by collecting sound or video through learning media that is linked to the internet network [11]. While learning without coordination is the delivery of material by teachers through internet learning media so that students can access material anytime and anywhere [12].

Learning to use the internet with special coordinated and uncoordinated techniques actually still creates a lot of chaos. Simultaneous learning such as using the zoom application or similar, in some cases there are internet connection problems that cause the delivery of material to be less clear and understanding of the material lacking [13]. This was also conveyed by Niken Bayu [9] that internet network-based learning makes it difficult for students to understand the concept of learning, due to the limitations of the teacher's explanation of the material, especially in delivering material online with uncoordinated techniques, where students find and understand the material themselves. in fact. This difficulty is also felt by arithmetic education students at UNMUH Ponorogo during the implementation of online-based learning, considering that the thinking in the courses taken by mathematics instruction students is more theoretical, especially in learning materials with higher problems that cause arithmetic education students to have difficulty understanding the material [14]. This makes students need to have more control in learning to achieve web-based learning goals. In accordance with the Directorate General of Teachers and School Personnel (Ditjen GTK), [15] which states that online learning requires students to create awareness, calm, seek information independently, be responsible and disciplined in learning.

The result of research from Canada [16] that the specific context of the pandemic disrupted more than normal teaching and learning activities. Whereas students generally responded positively to the transition, their reluctance to continue learning online and the added stress and workload show the limits of this large scale social experiment.

Learning discipline is an appropriate situation, where individuals (students) involved in learning interactions depend on the principles that have been set with full awareness without any intimidation, both structured and unwritten guidelines in making changes [17]. Learning disciplines are also characterized as learning conditions that are created and shaped through a series of cycles of student mentality and practice that show the qualities of obedience, approval, loyalty, routine, and perspective that are relied on to achieve learning goals [18]. This means that students who apply learning control will sort out themselves so that they can achieve the planned learning targets. The achievement of the target of taking can be seen from student learning outcomes. Student learning achievement in the academic field is generally indicated by the achievement index (IP) achieved [19]. Achievement records are the learning outcomes of learning exercises in further education that are psychological in nature and are usually determined through estimation and assessment. Therefore, learning discipline has a significant role in achieving learning targets which can be seen from learning outcomes.

Regarding the previous research directed by Laila [20] it was tracked that student-driven control affects their learning achievement, where students who have high learning discipline have better learning achievements than students who do not. Students who are used as research subjects are high school students and display numerical material in the form of flat sides. This exploration needs to be done for students on arithmetic material to test whether learning discipline also affects student achievement, one of which is mathematics learning students. Examination by Siti [21] shows that there is an effect of preparation for learning discipline on increasing student academic achievement (IP). For this situation, the increase in student learning achievement (IP) is influenced by learning discipline, especially the higher the learning discipline, the learning achievement will increase. The subjects of the exploration were students from Psychology UMM and it was carried out during the face-to-face learning process directly. Therefore, research is needed on the impact of learning discipline on the learning achievement (IP) of students studying online or on the internet.

Observing the explanation from the previous researcher and the assessment above, the researcher will direct a study which is named "The Effect of Network-Based Learning Discipline as an Indicator of Student Learning Outcomes of Mathematics Education UNMUH Ponorogo". The reason for conducting this research is to determine students' expectations in taking the results of learning disciplines during online-based learning and the 
relationship between learning disciplines and learning outcomes during online-based learning. This study will also examine the estimated results of learning disciplines using the internet for UNMUH Ponorogo students and how much influence these learning disciplines have on student learning outcomes. By realizing that learning discipline can be an indicator of learning outcomes and knowing the magnitude of the influence of learning discipline on learning outcomes during online learning, mathematics training students can improve learning outcomes by expanding their learning discipline. In addition, this exam can be considered by teachers in improving student learning discipline so that learning outcomes during internet-based learning increase.

\section{METHOD}

\subsection{Research Types and Areas}

Analysts in this study used a quantitative methodology, particularly through a review of several UNMUH Ponorogo students through filling out questionnaires. In this study, there are two factors that are considered, namely learning discipline as an independent variable or independent variable and learning outcomes as the dependent variable or dependent variable. This exploration was carried out at the Mathematics Learning Study Program, Faculty of Tarbiyah and Educator Preparation, University of Muhammadiyah Ponorogo which is located on Jl. Budi Utomo No. 10. Ronowijayan, Kec. Siman, Kab. Ponorogo, East Java.

\subsection{Research Subject}

In this study, the population is all dynamic students of the Arithmetic Learning Study Program, Faculty of Tarbiyah and Educator Preparation, University of Muhammadiyah Ponorogo in the 2018 to 2020 . The test in this test uses a simple random sampling strategy. The basic irregular examination procedure is to take individual samples by offering equal opportunities to community individuals to be tested [22]. The results of the delivery of the survey through questionnaires, obtained 67 students who have filled in the information, so the subject of this research is more than 67 students.

\subsection{Data Mining Instruments and Strategies}

The variety of information instrument is an estimation instrument used by researchers to obtain data about the factors to be studied [23]. The instruments used by the analysts in this study were a learning discipline poll and a data collection of study results cards (KHS) for arithmetic learning students in the even semester of the 2020/2021 academic year. The KHS information base containing the student's IP (Index. Achievement) scores is used as information on online learning outcomes, while the learning discipline poll is used as information on learning discipline. The learning discipline survey used in this study is in the form of a Google form which is then filled out by students according to the situation and conditions of network-based learning. This survey is summarized from Sri Septiyaningsih's argument [24] which is valid with reliability or unshakable quality of 0.865 . with high unshakable quality classification. The validity test used in this poll is the Product Moment Correlation, while the reliability test is carried out using Cronbach's Alpha prescription. The scale used in this survey is a Likert scale consisting of 4 answer choices, namely Consistent (K), Often (S), Rarely (J), Never (TP). In the value of the answer choice, Consistent $(\mathrm{K})$ got a score of 4, Often (S) got a score of 3, Rarely (J) got a score of 2, Never (TP) got a score of 1, while for negative articulation, the answer choice was Consistent (K) got 1, Ordinary (S) got 2, Rarely (J) got 3 , Never (TP) got 4 . The survey consisted of 16 statements out of 6 pointers with a network as shown in the attached Table 1

Table 1. Grid of learning discipline instruments

\begin{tabular}{|l|c|c|}
\hline \multicolumn{1}{|c|}{ Indicator } & Item number & Amount. \\
\hline Paying attention / listening to learning & $1,2,3$ & 3 \\
\hline Have responsibility & 4,5 & 2 \\
\hline Ready with learning equipment & 6,7 & 2 \\
\hline Seriously & $8,9,10$ & 3 \\
\hline Obey the rules related to learning & $11,12,13$ & 3 \\
\hline Doing self-control & $14,15,16$ & 3 \\
\hline Amount & & 16 \\
\hline
\end{tabular}

Negative explanation 
The method of collecting information in this research is by disseminating a survey of learning disciplines and assessment documentation. The use of learning discipline polls is completed by providing and distributing a Google form link via WhatsApp group for students majoring in arithmetic. Submission of polls to obtain information about student learning discipline, while documentation investigation is used to obtain information about student learning outcomes. Documentation is anything that provides substantial and significant data through composition, whether in writing, goods or images [25]. The documentation study method in this study is used as a basis for information on the achievement of Mathematics Learning Achievements for even semester students of the 2020/2021 academic year.

\subsection{Data Analysis}

The results of the internet learning discipline poll and the collected student IP (Achievement Index) information were then prepared and analyzed using Microsoft Excel 2010 and SPSS version 26 to find clear measurements and test speculations using basic direct relapse investigations. Unmistakable insights are measurements that describe or describe research results without making speculations [26]. The description of information includes the amount of information, the mean value, standard deviation, lowest value, maximum value, variance, and ideal score.

The theory testing in this examination was dissected using the Simple Linear Regression Analysis method. Linear regression is a measurable technique used to anticipate the value of $\mathrm{Y}$ (the dependent variable) of the given value of $X$ (one independent factor), the condition of the linear regression model is [27]:

$$
Y=a+b X
$$

In this study, simple linear regression analysis was used to estimate student learning outcomes depending on internet-based learning discipline scores. There is an old-style assumption test that must be met so that simple linear regression analysis is valid, so it is very important as an evaluator, especially the normative test, linearity test, and heteroscedasticity test. If the information is normally distributed, straight, and there is no manifestation of heteroscedasticity, then it is continued with the examination of simple linear regression analysis. The degree of significance $(\alpha)$ used in this study was 0.05 .

Regularity test is directed to decide whether the remaining quality factors of learning discipline and learning outcomes are delivered regularly. The regularity test in this investigation uses the Kolmogorov Smirnov test in SPSS 26. The information will be orderly if the asym value. Sig. (2-tailed) nonstandard residual $>0.05$. The linearity test was completed to decide whether there is a very large direct relationship between the two factors examined [28]. The decision-making model in this linearity test is to compare the level of significance (sig.) with the level of significance $(\alpha)$ of 0.05 . If the value of sig. deviation from lineartyy $>0.05$, then at that point there is a significant critical straight relationship between learning and learning outcomes. The heteroscedasticity test is directed to find out whether there is a lingering difference disparity for all perceptions in the regression model [29]. In this heteroscedasticity test, the analyst uses the Glejser test, which is regressing the independent variable with an undeniable absolute residual value (Abs_Res), in terms of the sig. value $>0.05$ then at that time there was no indication of heteroscedasticity in the regression model. The following stage is a simple linear regression analysis. The side effect of the regression test will create an ANOVA table, coefficients, and model summary. The dynamic standard of the ANOVA table is if the urgency value (sig.) $<0.05$ then the regression model can be used to anticipate learning outcomes, while the Coefficient table assumes significant value $<0.05$ there is an influence between learning discipline (variable $\mathrm{X}$ ) on learning outcomes (variable Y). Examination of the regression test table of the summary information model by comparing the $\mathrm{R}$ value and the level of significance. The test model assumes an $\mathrm{R}$ value $>0.05$, so the relationship between internet networkbased learning discipline and learning outcomes is solid.

Table 2. Statistical analysis results.descriptive learning disciplines and learning outcomes

\begin{tabular}{|l|l|c|c|c|c|c|c|}
\hline \multicolumn{1}{|c|}{ Variable } & N. & Mean & Standard Devise & Min & Max & Variance & Skor. Ideal \\
\hline Learning discipline & 67 & 48.493 & 5.7561 & & 63.0 & 33.133 & 64 \\
\hline Learning outcomes & 67 & 3.5646 & 0.14716 & 3.21 & 3.97 & 0.022 & 4.00 \\
\hline
\end{tabular}




\section{RESULT AND CONCLUSION}

As for research, information on network-based learning disciplines can be seen from the survey results, while the results can be retrieved from the IP (achievement index) of 67 arithmetic learning students at UNMUH Ponorogo. Information handled by descriptive statistical analysis with SPSS rendition 26 application to determine the size of the information, the mean standard deviation, the smallest value, the maximum value, the variance, and the ideal score. Next is a statistical analysis of the information on learning disciplines and learning outcomes presented in Table 2.

Judging from the table of results of the descriptive analysis of learning discipline variables above, it is known that the amount of information data is 67 , the average value is 48.49 , the basic value is 2.6 , the largest value is 63 , the standard deviation is 5.756, the change is 33.133, and the best value 64 . Variable learning outcomes, the size of the information obtained is 67 , the average value is 3.5646 , the standard deviation is 0.14716 , the basic value is 3.21 , the largest value is 3.97 , the fluctuation is 0.022 , and the best score is 4.00 .

The next stage is a hypothesis test that tries to reveal how big the network-based learning discipline variable is as an indicator of learning outcomes. The theory testing in this research is directed to use simple regression analysis examination. Before performing a simple regression analysis, it is important to test the old-fashioned presumption as a condition for the simple regression analysis examination model to be substantial as an assessor. The traditional assumption test in this study is the normality test, linearity test, and heteroscedasticity test.

First of all, the test of regularity / normality of the information obtained is to decide whether the residual values of the learning discipline factors and student learning outcomes are spread regularly. Next are the results of the regularity test for the variable of learning discipline information and student learning outcomes using the Kolmogorov-Smirnov One-Example Test which is presented in Table 3.

Table 3. Information regularity test

\begin{tabular}{|c|c|}
\hline & Unstandardized residual \\
\hline N & 6,7 \\
\hline $\begin{array}{c}\text { Asymp. Sig., (2- } \\
\text { tailed). 200c,d }\end{array}$ & $200^{c, d}$ \\
\hline
\end{tabular}

Considering the consequence table from the Kolmogorov Smirnov One-Example test over, the asym Sig. (2-followed) value is non-standard lingering from 0.200 . The significant value is 0.200 $>0.05$, this tends to be considered that the information is commonly disseminated. The following exemplary presumption test is a linearity test. The following are the consequences of the linearity test of learning discipline information and student learning outcomes which are presented in Table 4.

Table 4. Information linearity test

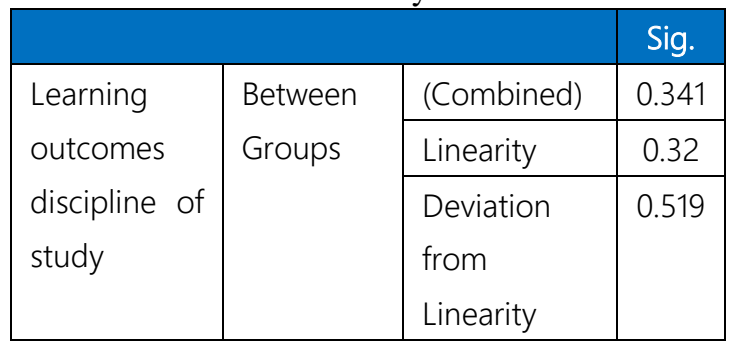

Judging from the table of consequences of the linearity test of the information above, the value of sig. The deviation from linearity is 0.519 . the value of importance $=0.519>0.05$, it can be concluded that there is a critical direct relationship between the learning discipline variable $(\mathrm{X})$ and the learning outcome variable (Y). The following exemplary assumption test is the heteroscedasticity test. This test was completed using the Glejser test. Next is the consequence of the Glejser test as information for this investigation, which is introduced in Table 5.

Table 5. Heteroscedasticity test

\begin{tabular}{|c|l|c|c|}
\hline Model & & $\mathrm{T}$ & Sig. \\
\hline \multirow{2}{*}{1} & (Constant) & 2.310 & 0.024 \\
\cline { 2 - 4 } & $\begin{array}{l}\text { Learning } \\
\text { Discipline }\end{array}$ & -1.146 & 0.256 \\
\hline
\end{tabular}

Judging from the results of the heteroscedasticity test above, the significant value (Sig.) of the learning discipline variable is 0.256 , where $0.256>0.05$, then at that time there is no heteroscedasticity in the regression model, in this way it meets the old-style assumption test.

The clarification above, tends to argue that a simple linear regression model of information is valid as an estimation tool because it has met the three old-style suspicion tests, to be more specific, inspection information is usually disseminated, there is a critical path. the relationship between learning discipline variables and learning outcomes variables, moreover, there is no heteroscedasticity in the regression model. Thus, speculative testing should be possible with simple linear regression investigations. Simple linear regression examination in this examination uses the SPSS form 26 
application. The consequences of the investigation are presented in Table 6.

Table 6. Information recurrence test (ANOVA)

\begin{tabular}{|c|c|c|c|c|}
\hline \multicolumn{2}{|l|}{ Model } & Df & F & Sig. \\
\hline \multirow{4}{*}{1} & Regression & 1 & 4.990 & 0.029 \\
\cline { 2 - 5 } & Residual & 65 & & \\
\cline { 2 - 5 } & Total & 65 & & \\
\hline
\end{tabular}

Based on the ANOVA information regression test table above, it is known that the determined $\mathrm{F}$ is 4.990 with a significant value (Sig.) $0.029<0.05$, so the regression model can be used to anticipate learning outcomes. The following regression examination is a test to determine the effect of learning discipline and learning outcomes by looking at the results of the SPSS coefficients. The side effects of these coefficients are introduced in Table 7.

Table 7. Information recurrence test (coefficient)

\begin{tabular}{|c|c|c|c|c|}
\hline \multicolumn{2}{|l|}{ Model } & \multicolumn{2}{|c|}{$\begin{array}{c}\text { Unstandardized } \\
\text { coefficients }\end{array}$} & \multirow{2}{*}{ Sig. } \\
\cline { 3 - 5 } \multicolumn{2}{|c|}{1} & B & Std.error & \\
\hline \multirow{2}{*}{1} & (Constant) & 3.234 & 0.149 & 0.000 \\
\cline { 2 - 5 } & $\begin{array}{c}\text { Learning } \\
\text { discipline }\end{array}$ & 0.007 & 0.003 & 0.029 \\
\hline
\end{tabular}

Based on the regression test coefficient table above, it is known that the significant value (Sig.) is 0.029 . The significant value is $0.029<0.05$, so at that point there is an influence between learning discipline (variable $\mathrm{X}$ ) on learning outcomes (variable Y). From a simple linear regression test table, a regression equation model can be made between learning disciplines and learning outcomes. The equation is as follows $\mathrm{Y}+3.234+0.007 \mathrm{X}$, where $\mathrm{Y}$ is the learning outcome variable, while $\mathrm{X}$ is the learning discipline variable. The value of a (unstandard coefficients esteem) in the condition of the regression equation is 3.234. That is, if there is no learning discipline in the internet network (variable $\mathrm{X}$ ), then the consistent value of learning outcomes (variable $\mathrm{Y}$ ) is 3.234. The value of $\mathrm{b}$ in the regression equation is 0.007 . This $b$ value indicates that for every additional 1 benefit of learning discipline (variable $\mathrm{X}$ ), then at that time learning outcomes (variable Y) increase by 0.007 . A follow-up effect of the following information regression test is the outline of the Summary model introduced in Table 8.

Judging from the data regression test table, the summary information model shows an $\mathrm{R}$ value of 0.267 , where the $\mathrm{R}$ value $=0.267>0.05$, then at that time the relationship between internet networkbased learning disciplines and learning outcomes was solid. The guarantee coefficient value ( $R$ Square) is 0.071 , which means that the impact of appropriate learning discipline on learning outcomes is $7.1 \%$, while $92.9 \%$ is influenced by various components that are not analyzed. The degree of accuracy of this test regression forecast is 0.14290 . It can be seen from std. The error estimate is 0.14290 in the table above.

As explained above, it shows that learning discipline can be used as an indicator of student learning outcomes at UNMUH Ponorogo Arithmetic School during internet-based learning. These results also indicate that there is a positive influence between network-based learning disciplines on learning outcomes which can be interpreted that if student learning discipline is high, student learning outcomes will also be high. This also applies vice versa, if student learning discipline is low, student learning outcomes will also be low. The learning discipline instructions in this exam which include being aware of other people's expectations, focusing or paying attention to study exercises, not joking, being ready to complete understanding, practicing restraint, and obeying the rules related to studying, these are things that every student should get results. learn true height to form. This is because students have an awareness of the expectations of others, focus or pay attention to learning exercises, do not joke, are ready to complete learning, adhere to principles related to learning, and are wise in their choices to get high marks. learning outcomes. In this study, the effect of student learning discipline during online learning on learning outcomes was $7.1 \%$, while $92.9 \%$ was influenced by various components that were not examined. Various factors that cause this situation can arise from within students such as learning fixation, learning inspiration, insight, and

Table 8. Test data regression model summary

\begin{tabular}{|c|c|c|c|c|}
\hline Model R & R & R Square & Adjusted R Square & Std.Error of the Estimate \\
\hline 1 & $267^{\mathrm{a}}$ & 0.071 & 0.057 & 0.14290 \\
\hline
\end{tabular}

- a. Predictor: (stable) learning discipline 
elements that come from outside students such as learning techniques and assessment approaches [30].

The results of this study are reinforced by the consequences of exploration conducted [31] who recommends that learning discipline affects student learning outcomes in mathematics training with a commitment to learning control on student learning outcomes by $15 \%$. In the research continued by [32], it was revealed that learning discipline has an impact on arithmetic learning achievement, where the higher the learning discipline, the higher the mathematics learning achievement. Moreover, research directed [33] found that there is a positive influence between learning disciplines on learning outcomes. For this situation, learning discipline has a significant role in studying student learning outcomes, especially during internet-based learning because students are required to take part in good learning even without a close and personal cycle with the teacher [34]. For this reason, students need to have the discipline of learning so that the steps of web-based learning run well so that students can achieve the learning objectives contained in the learning outcomes (IP).

\section{CONCLUSION}

The internet network-based learning discipline can be used as an indicator of student learning outcomes in the arithmetic department of UNMUH Ponorogo. For this situation, the discipline of learning in the internet network affects student learning outcomes and the two factors have a strong relationship. If students' learning discipline in network-based learning is higher, the learning outcomes will also be higher. Every 1 increase in learning discipline benefits (variable X), then at that time learning outcomes (variable Y) increased by 0.007 . The influence of internet network-based learning discipline on learning outcomes is $7.1 \%$, while $92.9 \%$ is influenced by different elements that are not analyzed.

Cycles in internet network-based learning, there are still several factors that affect student learning outcomes. This can be seen from the magnitude of the influence of different variables on student enrolment in the results of this study, which is $92.9 \%$. which shows that there are differences in variables that affect student learning outcomes. Thus, the analyst can encourage this examination by using other independent factors. Other than that. Scientists can encourage this examination by utilizing a wider range of examples to broaden the generalize of the consequences of their exploration.

\section{ACKNOWLEDGMENTS}

The author would like to thank Universitas Sebelas Maret.(UNS) for facilitating the completion of writing journal. The author also expresses his gratitude to the supervisor. Families who have provided financial assistance and enthusiasm, as well as input and opinions from friends in the completion of the journal.

\section{REFERENCES}

[1] Putria, H, Maula, L.H dan Uswatun, D.A. (2020). Investigasi Interaksi Pembelajaran Berbasis jaringan Internet Selama Pandemi Corona Oleh Guru Kelas. Jurnal Pendidikan, 4(4), 861-872.

[2] Dewi, W.A. (2020). Pengaruh Virus Corona Terhadap Pelaksanaan Pembelajaran Berbasis jaringan di Sekolah Dasar.Jurnal ilmu Pendidikan, 2(1),55-61.

[3] Fauci,A., Lane, H., \& Redfield, R. (2020). Covid-19- navigating the uncharted. New England Journal of Medicine, 382(13), 12681269. https://doi.org/10.1056/nejme2002387.

[4] Velavan, T., \& Meyer, C. (2020). The COVID-19 epidemic. Tropical Medisine \& International Health, 25(3), 278-280. https://doi.org/10.1111/tmi.13383.

[5] Daniel, S. (2020). Education and the COVID19 pandemic. PROSPECTS, 49(1-2), 91-96. https://doi.org/10.1007/s11125-020-094643 .

[6] Azorin, C. (2020). Beyond COVID-19 supernova. Is another education coming? Journal of Professional Capital and Community, 5(3/4), 381-390. https://doi.org/10.1108/jpcc-05-2020-0019.

[7] Handayani, D, Hadi, D.R, Burhan, E dan Agustin, H. (2019). Crown 19 Penyakit Infeksi. Jurnal Respilogi, 40(2),119-129.

[8] Handarini, O, I, dan Wulandari, S, S. (2020). Mengerjakan Internet Sebagai Ujian Dari Rumah (SFH) Di Masa Pandemi Virus Corona. Jurnal Ilmu Administrasi Perkantoran, 8(3),496-503.

[9] Argaheni,N.B. (2020). Audit Efisien: Pengaruh Online Talks Selama Pandemi Corona pada Mahasiswa Indonesia. Placentum jurnal ilmiah Kesehatan dan Aplikasinya,. 8(2), 99. 
[10] Loviana, S, dan Baskoro, W.N. (2020). Dampak Pandemi Corona terhadap Status Pembelajaran Aritmatika Tadris di IAIN Metro Lampung. Jurnal: Diary of Science Instruction STKIP-PGRI,2(1),61-70.

[11] Budiyanto, An dan Pujiyono, W. (2014). Pengaturan Broadcast Instructing and Learning Cycle dan Nonconcurrent. jurnal Perancangan Informatika, 2(1), 749-76.

[12] Divayana, G, H, Heryanda, K. K, dan Suyasa, P, A. (2020). Penguatan Pembelajaran Terkoordinasi dan Offbeat Bergantung pada Kualitas Berbeda dalam Suatu Karya untuk Meningkatkan Karakter Positif Siswa.ProcedingSenadimas Undiksha Kelima, September 307-316.

[13] Pratiwi, E.W. (2020). Pengaruh Virus Corona pada Latihan Pembelajaran berrbasis Internet di Sekolah Kristen di Indonesia. Sudut pandang Ilmu Instruktif.Jurnal: Pendidikan, 34(1), 1-8

[14] Kusumaningtum, B dan Wijayanto, Z. (2020). Apakah Pembelajaran Aritmatika Online Ampuh? (Analisis Kontekstual tentang Penjemputan Selama Periode Pandemi Coronavirus. Jurnal Aritmetika Kreatif Imajinatif, KREANO, 11(2), 136-142.

[15] Direktorat Jenderal GTK, Dinas Pendidikan dan Kebudayaan. (2016). Pedoman Khusus Program Peningkatan Pendidik Administrasi Sistem (On web) Model Pembelajaran Dakam. Jakarta.

[16] DJ Lemay, et al. (2021). Transition to online learning during COVID-19 pandemic. Computers in Human Behavior Report, 4(2021), 100130.

[17] E. Mulyasa. (2013). Program Pendidikan Berbasis Kemampuan. Bandung: PT. Pemuda Rosdakarya.

[18] Yuliantika, Siska. (2017). Investigasi Unsurunsur yang Mempengaruhi Tatanan Pembelajaran Siswa, Jurnal Education Vol: 9 No. 1 Tahun 2017.

[19] Hasanah, Fadiyah, L, Muzayyana, T, Hasanah, R dan Lindasari, Utami, D.L., dkk. (2019). Investigasi Hasil Belajar dengan Indeks Prestasi Kumulatif (IPK) Mahasiswa STAI At-taqwa Bondowoso. Jurnal Pelatihan dan Islam. 5(2), 29-39.

[20] Fitriana, L. (2011). Pengaruh Model Sistem Pembelajaran Bermanfaat Gathering Examination (GI) dan STAD Terhadap
Ketuntasan Belajar Matematika dengan Pertimbangan Understudy Control. Proceding Pelatihan Matematika dan Aritmatika, 319-336.

[21] Fatimah, Siti. (2013). Learning Control Untuk Meningkatkan Prestasi Belajar Siswa. Jurnal:Psikologi, 1(1), 145-155, 2013.

[22] Arieska,P.K, dan Herdiani,N. (2018). Penentuan Metode Pemeriksaan Bergantung pada Perhitungan Produktivitas Relatif. Semarang: PT Rineka Cipta.

[23] Nasution, H.F. (2016). Instrumen Pemeriksaan dan Kritisnya dalam Eksplorasi Kuantitatif, Al-Masharif: Jurnal Aspek Keuangan dan Ilmu Islam, 4(1),59-79.

[24] Septiyaningsih, S. (2019). Pengaruh Learning Exercises dan Learning Control Terhadap Prestasi Belajar Siswa Keuangan Persekolahan Angkatan 2013. Perguruan Tinggi Negeri Yogyakarta, 2019.

[25] Febrianti, Y. (2016). Mempelajari Kesiapan Kerangka Arsip (Arah, Sistem, dan Struktur) untuk Membantu Administrasi Mutu Perpustakaan. Studi Kesiapan Kerangka Laporan (Arah, Strategi, dan Struktur) Untuk Membantu Administrasi Kualitas Perpustakaan).Jurnal Pari, 2(2), 78-91.

[26] Sugiyono. (2012). Panduan Statistik Penelitian. Bandung: Alfabeta.

[27] Hijriani, A Muludi, K, and Andini, E.A. (2016). Eksekusi Model Regresi Linier Sederhan dalam Pengenalan Konsekuensi Antisipasi Penggunaan Air PDAM Way Rilau Kota Bandar Lampung dengan Kerangka Data Geografis. Jurnal Ilmu Informatika, 11(2), September, 37.

[28] Qomusuddin. JIKA. (2019). Pelatihan Wawasan (Lengkap Dengan Pengukuran IBM SPSS 20.0) Aplikasi. Sleman:Deplublish.

[29] Wardana. (2020). Prolog Aplikasi SPSS Rendisi 20. Yogyakarta: LPPM Perguruan Tinggi Muhammadiyah Buton Press.

[30] Dimyati, dan Mudjiono. (2013). Belajar dan Belajar. Jakarta: PT. Rinka Cipta.

[31] Marhama. (2017). Dampak Pembelajaran Kontrol Terhadap Hasil Belajar Siswa, Prosiding Seminar Nasional PGRI, 858-861.

[32] Silvia. (2016). Pengaruh Tata Tertib Belajar dan Kepedulian Wali Terhadap Prestasi 
Belajar Matematika. Jurnal: Perkembangan Pendidikan, 6(1),73-84.

[33] Setiawan, Andri. (2011). Pengaruh Pengetahuan Numerik Akal dan Urutan Belajar Terhadap Hasil Belajar Aritmatik. Perkembangan, Jurnal Perkembangan Pendidikan, 1(1),29-39.

[34] Badjeber, R. (2020). Disiplin Pembelajaran Mahasiswa Matematika Tadris FTIK IAIN Palu Selama Masa Pembelajaran Berbasis daring. Koordinat Jurnal Pembelajaran Matematika dan IPA, 1(1), 1-9. 